\title{
KIF11 Gene
}

National Cancer Institute

\section{Source}

National Cancer Institute. KIF11 Gene. NCI Thesaurus. Code C79078.

This gene plays a role in mitosis. 